\title{
Formation of Social Entrepreneurial Intention: A Qualitative Grounded Approach at the Base of the Pyramid
}

\author{
Frederik Claeyé ${ }^{1,2}$, Yosra Boughattas ${ }^{3}$ (i) and Erno T. Tornikoski ${ }^{4, *}$ \\ 1 Department of Management, ICHEC Brussels Management School, 1150 Woluwe-Saint-Pierre, Belgium; \\ frederik.claeye@ichec.be \\ 2 Department of Development Studies, Nelson Mandela University, Gqeberha 6031, South Africa \\ 3 Centre for Interdisciplinary Research in Management and Economics, Artois University, 62000 Arras, France; \\ yosra.boughattas@univ-artois.fr \\ 4 Centre for Entrepreneurship, University of Exeter Business School, Exeter EX4 4PU, UK \\ * Correspondence: e.tornikoski@exeter.ac.uk
}

Citation: Claeyé, Frederik, Yosra Boughattas, and Erno T. Tornikoski. 2022. Formation of Social

Entrepreneurial Intention: A Qualitative Grounded Approach at the Base of the Pyramid.

Administrative Sciences 12: 24 https://doi.org/10.3390/ admsci12010024

Received: 13 December 2021

Accepted: 31 January 2022

Published: 6 February 2022

Publisher's Note: MDPI stays neutral with regard to jurisdictional claims in published maps and institutional affiliations.

Copyright: (C) 2022 by the authors. Licensee MDPI, Basel, Switzerland. This article is an open access article distributed under the terms and conditions of the Creative Commons Attribution (CC BY) license (https:// creativecommons.org/licenses/by/ $4.0 /)$

\begin{abstract}
While there have been some attempts at investigating and theorizing social entrepreneurial action at the base of the economic pyramid, our understanding of the processes contributing to the formation of social entrepreneurial intention in contexts of extreme poverty remain limited. In this study, we aim to address this gap by providing a better understanding of the formation of social entrepreneurial intentions of youths at the base of the economic pyramid. Drawing on a qualitative grounded approach, we highlight the role of self-confidence, perceived self-efficacy and social ascension beliefs as important drivers in understanding the formation of social entrepreneurial intention of youths at the base of the pyramid. At a practical level, our study suggests that besides developing entrepreneurship-specific knowledge, support mechanisms should also pay attention to the development of different self-related beliefs of youths to enable the formation of social entrepreneurial intention at the base of the pyramid.
\end{abstract}

Keywords: base of the pyramid (BoP); social entrepreneurship; entrepreneurial intentions; self-beliefs

\section{Introduction}

It is widely acknowledged that the COVID-19 pandemic has had widespread socioeconomic consequences (Das et al. 2022). As a result, almost 150 million people are projected to fall into abject poverty. The resulting increases in poverty are largely concentrated in the already fragile regions of South Asia and sub-Saharan Africa, with impacts to be felt harder in urban rather than in rural areas (Laborde et al. 2021). Researchers have increasingly turned their attention to the emancipatory power of entrepreneurship (Rindova et al. 2009) and how it may be a mechanism for poverty alleviation (Sutter et al. 2019; Manzoor et al. 2019; Trivedi and Petkova 2021). The underlying argument is that through identifying and acting on opportunities, entrepreneurs are catalysts for structural change and institutional evolution (Naudé 2014). This line of thought is particularly relevant for social entrepreneurship and base-of-the-pyramid (BoP) approaches as mechanisms for addressing poverty and inequality (Murphy and Coombes 2009; Cañeque and Hart 2017; Périac et al. 2018). Increasingly, BoP strategies focus on co-creating value with the poor and empowering them to create their own enterprises (Simanis and Hart 2008). Similarly, social entrepreneurs are typically seen as agents of change (Dees 1998), who-drawing on a business logic - try to 'change the system' (Newey 2018) by implementing novel and entrepreneurial solutions to address social ills. (Murphy et al. forthcoming; Saebi et al. 2019).

A small but growing literature is budding at the intersection of social entrepreneurship and BoP strategies (Agarwal et al. 2018; Goyal et al. 2017; Claeyé et al. 2020). While there have been some attempts at investigating and theorizing entrepreneurial action among disadvantaged communities, our understanding of the processes contributing to 
the formation of social entrepreneurial intention at the BoP remain limited. We contribute to this line of research by investigating the following research question: How do social entrepreneurial intentions emerge at the base of the pyramid?

We investigate this question empirically by drawing on a qualitatively grounded approach. We collected data in Southeast Asia using an entrepreneurship program developed by a local NGO as our research setting. The youths at the BoP participating in our study (i.e., beneficiaries) had no prior intention to create their own social enterprise before joining the program. The contribution of our study lies in proposing a grounded cognitive model of social entrepreneurial intention of these youths at the base of the pyramid. To this end, our empirical findings highlight the role of self-confidence, perceived self-efficacy, and social ascension beliefs as important drivers in understanding the formation of social entrepreneurial intention at the BoP. At a practical level, our study highlights the importance of social support: besides developing entrepreneurship specific knowledge, support mechanisms should also pay attention to the development of different self-related beliefs of youths to enable the formation of social entrepreneurial intention at the BoP.

In the remainder of this article, we develop our argument as follows: first, we review the relevant literature on entrepreneurial intentions. We then outline the methodological approach adopted in this study. This is followed by the presentation of the findings and the discussion thereof. We conclude with some implications and avenues for further research.

\section{Theoretical Framework}

\section{1. (Social) Entrepreneurial Intentions}

Entrepreneurial intention represents a rapidly evolving field of research that has spawned a considerable body of literature since the 1990s (Dolhey 2019; Liñán and Fayolle 2015; Donaldson et al. 2021). As Krueger et al. (2000) argue, intentions are the single best predictor of any planned behavior, such as entrepreneurship. The two dominant models in the field are Ajzen's (1991) theory of planned behavior and Shapero's (Shapero 1984; Shapero and Sokol 1982) entrepreneurial event model (Donaldson 2019). Despite the existence of alternative models, there is some evidence of the compatibility of these intention-based models (Liñán and Fayolle 2015).

Drawing on Ajzen's (1991) theory of planned behavior and Shapero's (Shapero 1984; Shapero and Sokol 1982) entrepreneurial event model, Krueger (2009) proposes an integrated model of entrepreneurial intentions. He suggests that entrepreneurial intentions first require some sort of precipitating factor, which can take the form of some kind of perceived facilitating factor or the removal of a perceived barrier. The resulting behavior of a potential entrepreneur depends on the perceived desirability and perceived feasibility of a particular course of action. Perceived desirability is mediated by personal desirability, that is, the personal attractiveness of starting a business in terms of the expectations and beliefs one holds about personal impacts of outcomes resulting from a particular behavior (Krueger et al. 2000). Secondly, perceived desirability is mediated by perceived social norms, that is one's perception of what significant people in their lives would think about starting a business (Krueger et al. 2000).

Perceived feasibility, in turn, depends on perceived self-efficacy, that is, one's perceived ability to execute a behavior required to produce an outcome, in casu, setting up a new venture (Krueger et al. 2000). However, economically disadvantaged communities often suffer from deficits in self-efficacy (Krueger and Brazeal 1994; Kushnirovich et al. 2018). Furthermore, research on the psychology of poverty has shown poverty has detrimental effects on, inter alia, individuals' sense of self-confidence (Carr 2013; Carr and Sloan 2003; Haushofer 2013), which may undermine people's goal-directed behaviors (Haushofer and Fehr 2014), such as enterprise creation.

Perceived feasibility also depends on perceived collective efficacy, that is, a group's belief in their conjoint capabilities to organize and execute the courses of action required to produce given levels of attainments (Shepherd and Krueger 2002). While this has been mainly theorized in terms of organizational teams, this could be expanded to the community 
level to include perceived collective capacity to take coordinated and interdependent action on issues that affect the community. As Bandura (2000) indicates, many of the outcomes people seek to attain are achievable only through interdependent efforts.

Finally, Krueger (2009), drawing on Shapero and Sokol (1982), contends that a potential opportunity must be perceived as both desirable and feasible by a potential entrepreneur. Before this perceived opportunity is acted upon, another antecedent, propensity to act, is important. For Shapero and Sokol (1982), propensity to act is conceptualized as the personal disposition to act on one's decisions. Hence, if one's propensity to act is low, attitudes may be less predictive of intention and action and vice versa (Krueger 1993). Figure 1 below captures Krueger's (2009) integrated model of entrepreneurial intentions.

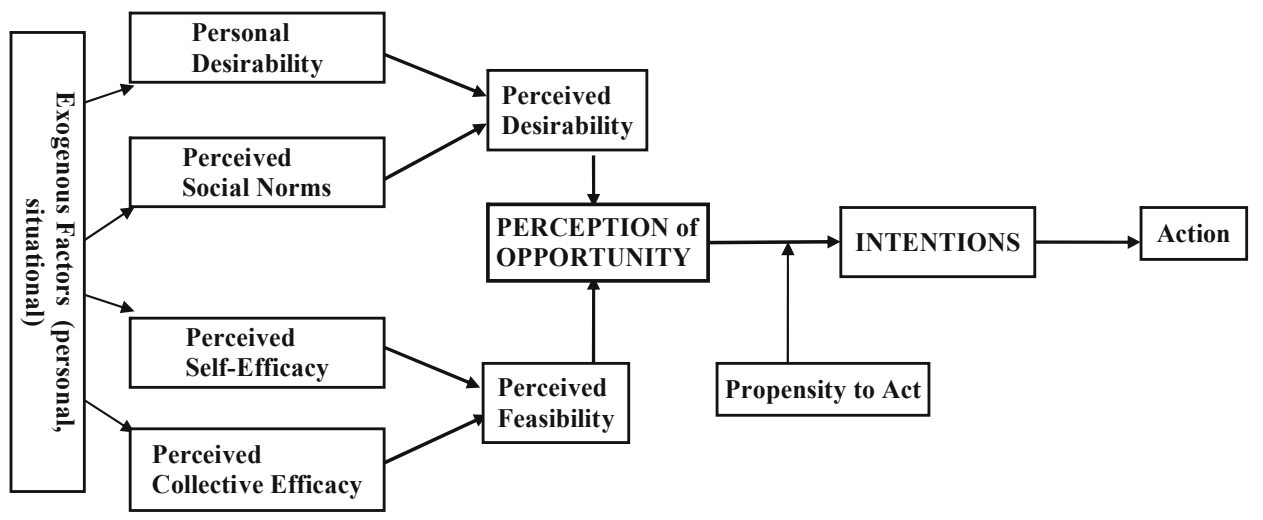

Figure 1. Intentions model (Krueger 2009, p. 58).

As Liñán and Fayolle (2015) contend in their systematic review of the entrepreneurial intention literature, social entrepreneurial intention has recently strongly emerged as a research topic (see Tan et al. 2020 for a recent systematic review). For the purposes of this study, we define social entrepreneurs as individuals (or groups of individuals) setting up and running organizations that aim to create social value by addressing social, economic, or environmental problems (Mair and Martí 2006). Research on social entrepreneurial intentions has increased considerably over the last decade. Nevertheless, with the exception of notable examples such as Ip et al. (2021) or Yamini et al. (forthcoming), most contributions draw heavily upon and are an extension of the conventional entrepreneurial models outlined above (Tan et al. 2020).

Drawing on Ajzen's (1991) theory of planned behavior, Mair and Noboa (2006) were the first to advance theoretical propositions about the antecedents of social entrepreneurial intentions. In their propositions, they suggest empathy as a proxy to Ajzen's (1991) notion of attitudes toward behavior (personal desirability in the figure above), and moral obligation as a proxy to Ajzen's (1991) notion of social norms. In addition, they suggest that selfefficacy and social support affect perceptions of social venture feasibility.

Mair and Noboa's (2006) proposition of four antecedents of social entrepreneurial intent were tested and extended subsequently by a number of scholars. For example, Bacq and Alt (2018) further refine the empathy construct by highlighting that empathy explains social entrepreneurial intentions through two complementary mechanisms: self-efficacy as an agentic mechanism and social worth as a communal mechanism. Hockerts (2017), extends the model by including prior experience with social problems as an additional variable. His study shows prior experience predicts social entrepreneurial intentions and that this effect is mediated by the antecedents suggested by Mair and Noboa. Hockerts (2017) study indicates that self-efficacy has the largest impact on intentions as well as itself being most responsive to prior experience. Usman et al. (2022) further extend Mair and Noboa's (2006) framework by highlighting the influence of social impact and social worth on social entrepreneurial intentions. However, most of these studies have been conducted in more affluent societies or with members of the more affluent segments of society in 
developing nations. To date, we lack a clear understanding of the formation of social entrepreneurial intention in the context of extreme poverty at the BoP. In the following section, we outline what is currently known regarding enterprise creation at the BoP.

\section{2. (Social) Enterprise Creation at the Base of the Pyramid}

Prahalad and Hart (1999) introduced the notion of the base of the pyramid (BoP) as a new profitable market for multinational companies that consists of the four billion people whose per capita income is less than USD 1500 per year. Since its introduction in 1999, the concept has shifted from an emphasis on the on selling goods and services to the poor (BoP 1.0; Prahalad and Hart 1999), overseeing them as potential business partners (BoP 2.0; Simanis and Hart 2008), to focusing on a bottom-up sustainable development approach "in which the small producers, poor and impoverished [ ... ] are the main protagonists" (BoP 3.0; Pedrozo 2015, p. 190; for a recent review, see Dembek et al. 2020) As such, the different BoP strategies share the emancipatory agenda that characterizes social entrepreneurship. While research at the intersection of these two streams of scholarship is rapidly growing (Agarwal et al. 2018; De Beule et al. 2020; Sottini et al. forthcoming), scant attention has been dedicated to the process of social entrepreneurial intentions formation at the BoP. Therefore, in the following paragraphs, we mainly focus on what is known about enterprise creation at the BoP.

In their systematic review of gender and poverty entrepreneurship, Santos and Neumeyer (2021) highlight that, overall, female BoP entrepreneurship is driven by push factors linked to a desire to improve the current situation. These include a desire to better one's income and gain more personal freedom, security or recognition. For example, investigating a self-help group in India, Chatterjee et al. (2018) found that it helps to empower women to become micro-entrepreneurs. Women participating in the self-help group gain access to different forms of financial assistance, communication and network facilities, as well as social recognition. This leads to greater empowerment and causes the decision to become a micro-entrepreneur. In this regard, Santos et al. (2019) introduce the notion of 'entrepreneurial empowerment', whereby entrepreneurial empowerment shapes attitudes and intentions over time, the outcomes of which may, in turn, impact entrepreneurial empowerment (see also Morris et al. 2020). Taking an identity-based approach, Musona et al. (2021) highlight that both social and role identities influence opportunity recognition, but that role identities (i.e., an individual's interpretation of what it means to be an entrepreneur) result in behavioral differences amongst nascent entrepreneurs with the same social identities as they engage in enterprise creation activities.

Acheampong and Esposito (2014) found that psychodynamic factors are more important than trait factors in explaining BoP entrepreneurship in Ghana. As such, they posit that entrepreneurial behavior is driven by a childhood of deprivation and that this helps nascent entrepreneurs to understand the nature of poverty and provides them with insights that enable them develop product and services to meet the needs of the poor. Similarly, among the three motivational factors Henning and Akoob (2017) found, 'destitute conditions' was ranked as the most important reason for starting an informal business. This is echoed by Dye and Dye (2018), who found that their respondents saw entrepreneurship as a way to resist and move beyond conditions of socio-economic deprivation (see also Miller and Le Breton-Miller 2017). In a similar vein, looking at the effects of consumption constraints on entrepreneurial intentions, Venugopal et al. (2015) showed how chronic constraints amplify entrepreneurial intentions and how marketplace literacy education enhances entrepreneurial self-efficacy. Bullough et al. (2014) found that under conditions of war, individuals develop entrepreneurial intentions if they are able to grow from adversity (resilience) and believe in their entrepreneurial abilities (entrepreneurial self-efficacy). Yessoufou et al. (2018) found that entrepreneurial processes at the BoP emerge primarily from external factors such as challenging circumstances and disruptive events (see also George et al. 2013). They put forward six propositions about the entrepreneurial process at the BoP (pp. 13-16): 
1. Entrepreneurial processes at the BoP emerge primarily from external factors such as challenging circumstances and disruptive events.

2. The entrepreneurial opportunity exploitation results from opportunities developed by learning.

3. Entrepreneurs' motivations of self-fulfillment, income generation and wealth creation strengthen the relationship between opportunity development and challenging situations.

4. The willingness to structure income uncertainty moderates the relationship between challenging circumstances/disruptive events and opportunity development.

5. Human agency moderates the relationship between opportunity development and opportunity exploitation. The stronger the ability of an entrepreneur to respond to challenging situations or events in developing entrepreneurial opportunities, the more likely and easier the exploitation of entrepreneurial opportunities.

6. The ability of the entrepreneur to network moderates the move from opportunity development to opportunity exploitation. The stronger the ability to identify and create supportive networks, the more likely the exploitation of entrepreneurial opportunities.

Some parallels can be drawn here with our earlier discussion on entrepreneurial intentions. As in Krueger's (2009) intention model above, exogenous factors in terms of chronic constraints or disruptive events are put forward to act as a trigger event that induces the entrepreneurial intent. Proposition three on personal motivations is reminiscent of personal desirability and the beliefs one holds about personal impacts of outcomes resulting from a particular behavior. Both propositions four and five refer to one's propensity to act. However, neither learning (proposition two) nor social capital (proposition six) are incorporated in Krueger's (2009) integrated intentions model. BoP studies suggest that these may be important additional factors to consider as well. While social capital (proposition six) may be partially captured by Krueger's (2009) in terms of one's perception of what significant people in their lives would think about starting a business (perceived social norms), it falls short of more traditional conceptions of social capital as the ability of actors to extract benefits from their social structures, networks and memberships (Davidsson and Honig 2003).

As a summary of the literature review, there are some visible disparities between how existing intention models have theorized the emergence of social entrepreneurial intention in general. Additionally, only a few studies concern the formation of social entrepreneurial intentions at the context of base of the pyramid. Indeed, an overwhelming majority of previous intention studies take place in developed countries or focus on more affluential people in developing countries. The theoretical and empirical gaps invite us to propose a more qualitative, explorative approach to shed light on the emergence of social entrepreneurial intentions at BoP, which we detail next.

\section{Materials and Methods}

This paper addresses the following research question: How do social entrepreneurial intentions emerge at the base of the pyramid?

There have been a number of quantitative studies into SEI (Zhang et al. 2021; Hockerts 2017) that are mostly based on deductive theory building from area outside the SE domain and that rely on affluent societies or members of more affluent groups in developing nations. We know very little about SEIs of poorer segments of society. This misses the context specificity of SEI formation. By adopting a qualitative, explorative approach, this study addresses this gap by focusing on situated human actions and their meanings (Saldaña and Omasta 2018), and thus, by moving away from variance-based approaches, gives us a richer and more contextualised understanding of the processes and practices underlying SEI formation in the context of BoP (Tracy 2020).

The following paragraphs detail the research setting, how and which data were collected, and how they were subsequently analyzed. 


\subsection{The Research Setting}

This research is set in an NGO-run entrepreneurship program, launched in Southeast Asia. The program runs for two years and provides a hands-on approach to learning how to develop rural areas. It is presented as the first social entrepreneurship program for the poorest of the poor (i.e., beneficiaries). During the program, the beneficiaries attend a variety of courses that focus on character development, enterprise management, communications, business mathematics, and agriculture. At the same time, they participate in all the activities of the NGO, such as cleaning the common areas and preparing meals. Besides the classroom instruction, hands-on learning, and enterprise development, the beneficiaries become partners or apprentices of existing social enterprises through the Gap Year Program, which allows them to continue the application of real-world skills.

\subsection{Data Collection}

The methodological approach taken rests on a qualitative grounded approach. For the examination of ongoing human activity at the BoP, a qualitative approach allows for a richer understanding of the actions and the socio-historical context of poverty that precedes individual motivations and actions at the BoP (Tracy 2020). Our data collection involved in situ participant observation, semi-directive interviews, as well as some life stories of beneficiaries. In 2018, we conducted 20 narrative interviews with beneficiaries of the program. This represents just under $40 \%$ of the beneficiaries enrolled in the program at that time. In addition, we felt that saturation had been achieved as new cases did not contribute any new information (Francis et al. 2010). We adopted a non-probability, purposive maximum variation sampling approach and selected instances that were information rich with a view to answering our research question (Schreier 2018). These data were supplemented with observation field notes (eight days) and three interviews with people in charge of the program to obtain some background information on the program and cross-check statements made by the beneficiaries we interviewed. Table 1 below summarizes the beneficiaries' characteristics.

Table 1. Characteristics of interviewed beneficiaries.

\begin{tabular}{cccccc}
\hline Initials & Activity & Gender & Age & $\begin{array}{c}\text { Previous } \\
\text { Education }\end{array}$ & $\begin{array}{c}\text { Year in the } \\
\text { NGO }\end{array}$ \\
\hline R1 & Snacks & M & 20 & College & 2nd year \\
\hline R2 & Graphic design & M & 19 & High School & 1st year \\
\hline R3 & Coffee & F & 18 & $\begin{array}{c}\text { College } \\
\text { dropout }\end{array}$ & 2nd year \\
\hline R4 & Fashion and textile & F & 20 & High School & 3rd year \\
\hline R5 & Snacks & M & 18 & High School & 3rd year \\
\hline R6 & Cocoa ice coffee & F & 21 & High School & 1st year \\
\hline R7 & Dairy & F & 19 & High School & 2nd year \\
\hline R8 & Not yet chosen & M & 22 & High School & 1st year \\
\hline R9 & Food production & F & 20 & High School & Gap year \\
\hline R10 & Snacks & M & 18 & High School & 2nd year \\
\hline R11 & Pet shop & M & 22 & High School & 2nd year \\
\hline R12 & Food & F & 18 & High School & 2nd year \\
\hline R13 & Restaurant & F & 22 & $\begin{array}{c}\text { College } \\
\text { dropout }\end{array}$ & 2nd year \\
\hline
\end{tabular}


Table 1. Cont.

\begin{tabular}{cccccc}
\hline Initials & Activity & Gender & Age & $\begin{array}{c}\text { Previous } \\
\text { Education }\end{array}$ & $\begin{array}{c}\text { Year in the } \\
\text { NGO }\end{array}$ \\
\hline R14 & Coffee & M & 23 & $\begin{array}{c}\text { College } \\
\text { dropout }\end{array}$ & 1st year \\
\hline R15 & Coffee & M & 20 & High School & 3rd year \\
\hline R16 & Landscaping & M & 25 & $\begin{array}{c}\text { High school } \\
\text { dropout }\end{array}$ & 1st year \\
\hline R17 & $\begin{array}{c}\text { Lemongrass tea with } \\
\text { ginger/"medicine" }\end{array}$ & F & 18 & High school & 1st year \\
\hline R18 & $\begin{array}{c}\text { Still in ideational } \\
\text { phase }\end{array}$ & F & 18 & High School & 1st year \\
\hline R19 & Fruit tree industry & F & 20 & High School & 2nd year \\
\hline R20 & Snacks & M & 22 & High school & 2nd year \\
\hline
\end{tabular}

\subsection{Data Analysis}

This exploratory study is based on the principles of grounded theory from the perspective of Strauss and Corbin (1990) and Gioia et al. (2013). In line with these authors, in our study, we take an inductive approach grounded in the lived experience of the beneficiaries and how they make sense of different experiences during the NGO-run program to develop concepts that we subsequently put in dialogue with existing literature. The data collection was carried out by only one researcher among the three authors of this article (insideroutsiders perspective). We looked to identify significant recurrences, as this relates to the researchers' attribution of meaning. The interview data were then analyzed thematically by the authors using a combination of manual thematic content analysis and more systematic content-sorting using QSR NVivo 11. We have devised a systematic inductive approach to concept development.

First, we codified each idea with a concept and then modified the concepts as needed to ensure that the revisited data fitted well with the category. We assigned in vivo codes based on themes generated directly from the language used by the interviewees (Corley and Gioia 2004).

Second, we used axial coding by identifying similarities between concepts in order to create consolidated categories of a higher nature. For example, we created a secondorder code named "prior experience with poverty" from first-order codes such as "hunger, survival, resourcefulness".

Third, we selected the central idea that emerged from the axial coding and we created the final aggregate dimension by gathering the theoretical categories from the secondorder codes. In parallel to these three steps, were confronted the emerging codes with our participant observations notes. Taking notes in situ involves learning about a culture from within (Miles et al. 2014).

Data were analyzed by these three researchers. Authors one and two performed the analysis and categorization. The third author took on the role of reader to challenge the initial conceptualizations and to improve the intercoder reliability. Data were triangulated until saturation was achieved.

Thus, the code "perceived self-efficacy" is aggregated from the prior experience of the beneficiaries with poverty, the formal education, and the hands-on experimentation provided by the NGO. The findings are presented in the data structure (Figure 2 below). This data structure overview is based on the three steps required by this methodology, from first-order codes to aggregate dimensions. 


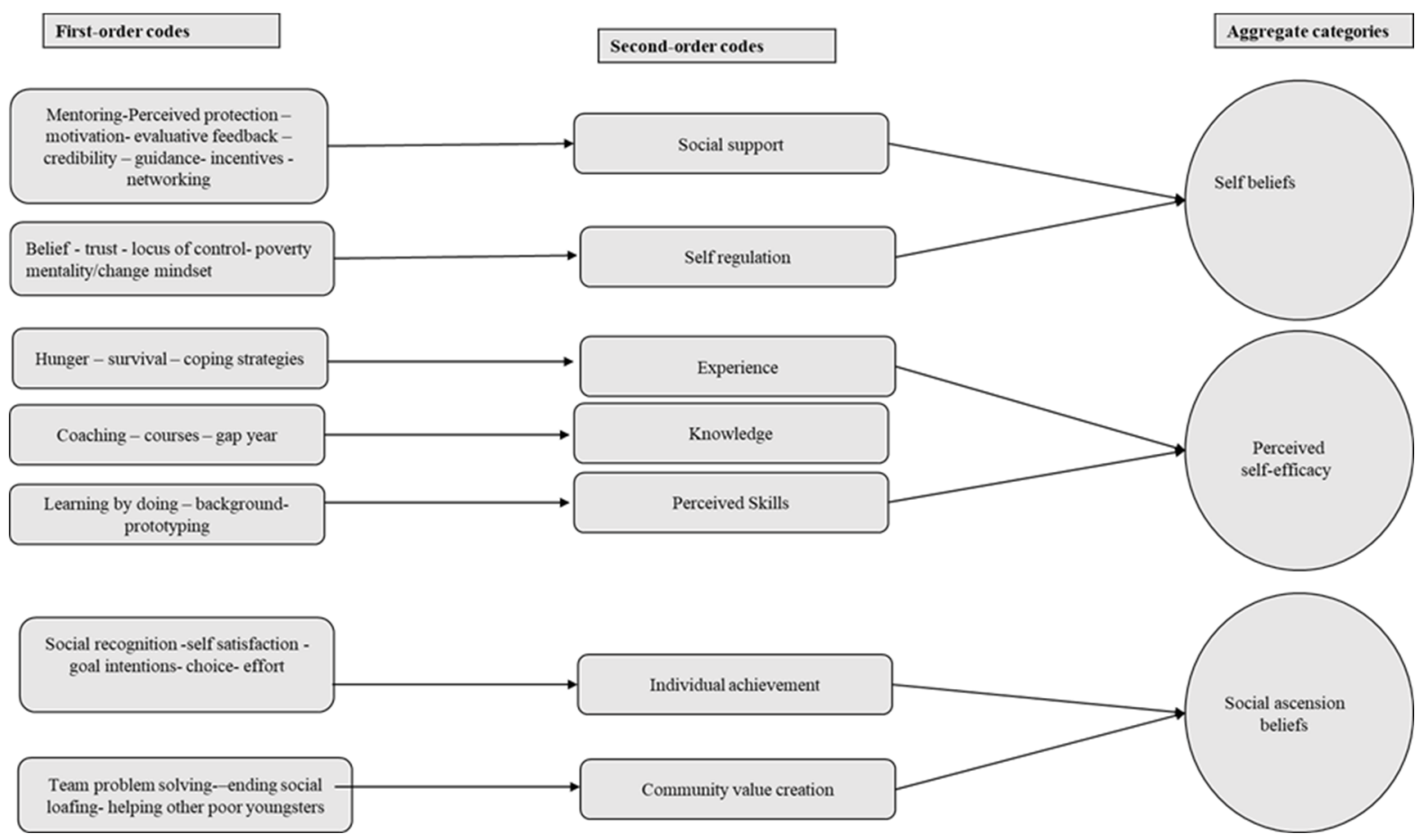

Figure 2. Data structure.

Finally, we provide a resulting grounded theory model (Figure 3 below) by oscillating between emergent data, concepts, and the relevant literature. This model describes and explains the dynamic relationships among the emergent concepts and makes clear all relevant data-to-theory connections (Gioia et al. 2013). Our goal is to highlight new insights with regard to the emergence of social entrepreneurial intention at the base of the pyramid.

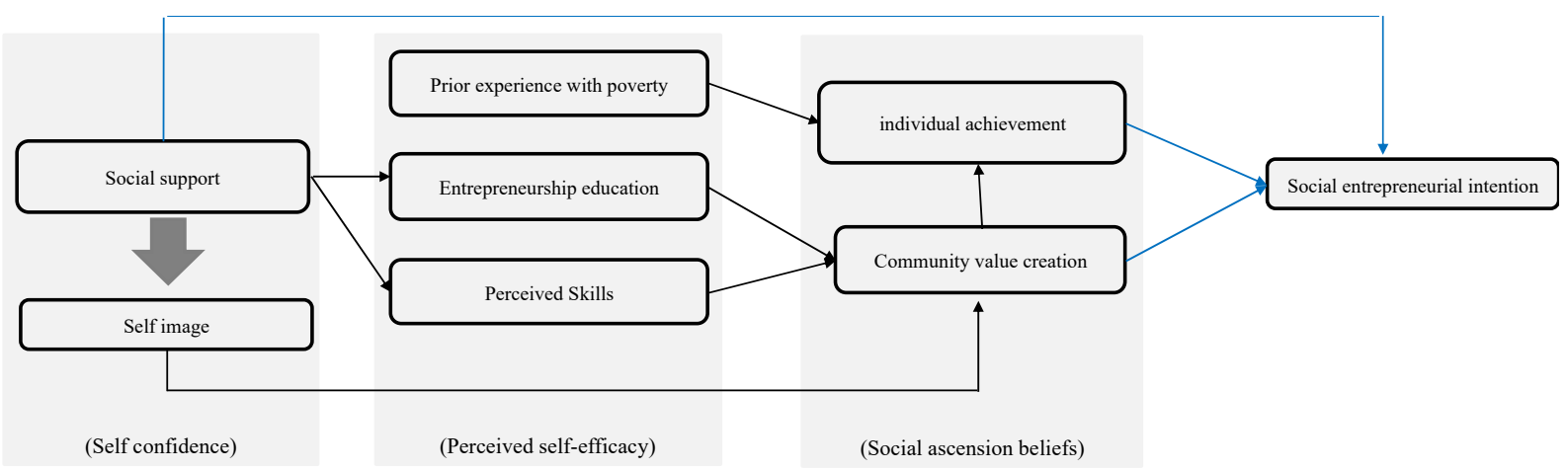

Figure 3. Grounded model of SEI at BoP.

\section{Results}

Three aggregated dimensions (see data structure in Figure 2) emerged as strong drivers of social entrepreneurial intentions of the beneficiaries: perceived self-efficacy, self-confidence, and social ascension beliefs. Our findings propose a grounded model of social entrepreneurial intention at the base of the pyramid hereafter (Figure 3).

\subsection{Self-Confidence}

Firstly, we found that "self-confidence" is a central issue in understanding the emergence of social entrepreneurial intention among the beneficiaries participating in our study. Beneficiaries talked about the need to first overcome a 'poverty mindset' that downgrades the poor to think that they cannot achieve anything in life. Beneficiaries indicated a sense of regaining "self-confidence" to express their changing mentality and attitude. 
"So, I wanted to share with you how [the program] and [the NGO] molded me into a better person of myself, to be confident, to love and care." (life stories)

"So, my life before is so, I am so shy, so timid and I don't want to talk to other people. They, the mentors help us to build our confidence, ourself." (R10)

"They are not just teaching us about the subjects that they are teaching, but they are also encouraging [us], motivate [us] really to be confident enough and the determination to become a social entrepreneur." (R7)

The beneficiaries also stressed the importance of an environment in which trust is key in organizing social relationships as an important aspect in the development of their self-confidence.

"I learn value, those people who trusted you, the people who bestow their trust, their time in you because before I had a hard time of believing people. I had a hard time of trusting people, but then when I came here, [ . . . ] they teach me [..] the lesson in life that no man is an island." (R1)

"But still [name of mentors] always trusts us, and we have that values transformation [ ... ] And they, as they always said that they will never give up on us if we don't give up on them. I think it is just trust." (R18)

"The trust in each other because here we really came from different places and most of us [ ... ]; look most of us experience hunger in our, some of us need to steal in order to survive [ ... ]. But then the trust; it always builds us." (R12)

The beneficiaries evoke a mutual and reciprocal trust between them and the community members and staff. One important element in building beneficiaries' self-confidence is building trust. Beneficiaries indicated there are several institutionalized moments, both individual and collective, that are instrumental. For example, they organize a regular collective session, where beneficiaries share their experiences and listen to the experiences of others in order to learn from each other and move forward, both collectively and as individuals. As one mentor put it: "Because every week we have the solidarity assembly where we start off Mondays at 7:30 just to talk about some values, to reflect on that. So, we reflect on them; so even those moments it's part of the curriculum so that we can engage them and try to develop the best out of them." This social support enhances beneficiaries' self-image and changes their perception of the self. As such, developing self-confidence through the mechanisms outlined above is a first crucial steppingstone in the emergence of social entrepreneurial intention. It directly feeds into perceived self-efficacy, which we discuss in the following section.

\subsection{Perceived Self-Efficacy}

While beneficiaries are attracted to the program by a desire to escape poverty and hunger, most of them arrive at the program without any prior knowledge about how to set up their own venture. Many beneficiaries who arrive at the program are characterized by the 'poverty mindset' we touched upon above. Our data suggest that perceived self-efficacy is constructed through the program in which emotional and technical social support is a key element. This social support focuses on remedying the beneficiaries' 'poverty mindset' and building their self-efficacy (through enhancing their self-confidence, as we discussed above) through valuing their previous experience with hunger, hands-on experimentation, and entrepreneurship education. In this regard, the beneficiaries indicated:

"I think it's the motivation part. Because it pushed me to believe that I can do that thing [social entrepreneurship], I can make things possible." (R1)

“Well at first I don't want to be a, way back in my past, I don't want to enter into business because I'm not good in math, like that and also I'm not good in English and this one my weaknesses before, but now I thought that now, I thought that "yes, I am so excited". Instead of afraid I'm excited that someday it will be and work." (R2) 
"Because I am, like, I am led to be a great entrepreneur by the people [that] surround me and also my mentors, especially the people in my community." (R18)

Through the program and the support given by the mentors and the program in which they are embedded, the beneficiaries start to shed the 'poverty mentality', which held them back, and start believing in themselves as individuals and potential social entrepreneurs. By becoming more self-confident individuals that believe in their own competences and capacities, their perceived self-efficacy grows. Even though, at this point in time, many beneficiaries indicated that they still felt unsure about their skills or knowledge to become successful social entrepreneurs, they were confident that they would learn and acquire the knowledge, skills and expertise required to become successful social entrepreneurs through their hands-on experiences during the program. Echoing a feeling echoed by many of the beneficiaries we interviewed, the same beneficiary as above, explains that:

"I don't think so I have a knowledge, like, but I feel, I feel it in my heart like I just don't know I don't have a knowledge, I don't have an experience of being a social entrepreneur. But here it, here [touches heart] it tells my mind that I can be a social entrepreneur that I can manage if I will be a good entrepreneur." (R18)

This building of self-efficacy through working on their self-confidence, providing them with formal skills and knowledge and a space to experiment helps the beneficiaries to look at the future as social entrepreneurs. When asked where they saw themselves five years from now, most beneficiaries saw themselves as being successful social entrepreneurs.

\subsection{Social Ascension Beliefs}

As indicated above, the beneficiaries join the NGO's entrepreneurship program based on a desire to break the poverty cycle in which they (often already for generations) had be trapped. Escaping the slums, the destitution, hunger and violence that accompany life in such conditions of extreme poverty thus become a strong driver for the beneficiaries' entrepreneurial intention. Their desire for social ascension not only focuses on themselves but also on emancipating their family, their community and their country from poverty. Social enterprises are seen as vehicles through which this social ascension may be achieved.

"And if I just go around with them [in the slums], there is nothing to help me. But if I do this job [NGO program] it really helped me a lot and I will choose this job [becoming a social entrepreneur] because this job will give me the potential to reach my goal in life, so like that." (R14)

"We are all working with one goal and that is just to end the poverty." (R8)

"Yes, it is really important for me because it could be the start of a better life for me and my family and, of course, my country." (R5)

I will be able to end my own poverty and end it for my family and my community as well, [ ... ] through this enterprise, I think and I know that we can earn a lot of money and we can help other people to end also their poverty. (R9)

As demonstrated by the last two statements, not only their own social ascension but also the emancipation of loved ones and the community to which they belong is important to them. This idea that social entrepreneurship may be a way out of poverty for themselves, their families and communities is a fundamental tenet of the program. A central place in trying to achieve the social ascension through eradicating poverty and uplifting the community is taken up by local notions of 'walang iwanan' (leaving no one behind) and 'bayanihan' (collective work). Beneficiaries explained its importance as follows:

"We have this sense of a really strong family. It is, we call it, walang iwanan, nobody is left behind. It's that strong sense of family that I really don't want to leave them. I know how it feels like when someone left me." (R4) 
"Bayanihan is working together, literally, like working together, [ ... ] to really meet the goal. When we meet the goal, there is the victory, that's maybe our goal, to really meet the victory. That's why people here when they need help, we call it bayanihan. We want to see everyone's victory in ourselves, victory in the place and all over here in [the program." (R8)

As the fragments above highlight, beneficiaries are imbued with the idea that social entrepreneurship is a way out of poverty at both the individual and community level. This sense of community, which is also strongly present in local culture, informs the social entrepreneurial intention and functions as a strong motivating factor for beneficiaries who want to lift their communities out of poverty through their social enterprises.

\section{Discussion}

\subsection{Contributions}

Our exploratory study, rooted in a qualitatively grounded approach, is concerned with elucidating some of the disparities between various models of social entrepreneurial intention with a view to clarify the emergence of social entrepreneurial intention at the base of the pyramid.

First, conventional wisdom posits a positive link between education and entrepreneurial intention (Raposo and Paço 2011). While our study is in line with these studies, it posits the importance of cognitive social support in the creation of social entrepreneurial intention at the base of the pyramid. In fact, our data suggest that the three mechanisms we described above are key to the emergence of social entrepreneurial intention among the beneficiaries we studied. However, the emergence of such social entrepreneurial intention does not occur in a vacuum. It emerges at the interface of personal drivers and the specific environment created by the NGO and the program it has developed. As already noted above, beneficiaries need to overcome a 'poverty mindset', which holds them back. For this reason, the entrepreneurship program that the NGO runs is developed and designed to work on this cognitive aspect in parallel with providing access to hands-on learning and business development opportunities. This 'values transformation', as they call it, is embedded in a strong support component that aims to develop beneficiaries' trust and self-confidence.

This social support extends in two dimensions, namely the individual support that is institutionalized in one-to-one sessions, and the collective support that is institutionalized in the weekly 'Solidarity Assemblies'. The notions of bayanihan and walang iwanan are strongly embedded in the latter. As highlighted earlier, these principles of bayanihan and walang iwanan go hand in hand with the strong sense of belonging to a community, a family. This is important for beneficiaries who in many cases have never left their home community before and are now sometimes living thousands of kilometers away from their relatives. In addition to providing some homely warmth, it also gives beneficiaries support in persevering.

In this family, the most important role is taken up by the mentors who live with the beneficiaries and provide them with both personal, emotional and academic support. Mentors play an important role in helping to change the mindset of beneficiaries and build their self-confidence and self-efficacy. Entrepreneurship literature has showed that an entrepreneur's social network is both an important source of information and at the same time an important influence on the way an entrepreneur thinks (Gaglio and Winter 2009). In the NGO-run program, mentors mobilize cognitive processes to assist beneficiaries in developing entrepreneurship specific knowledge and establishing strategies for managing their time and their goals.

While the program run by the NGO is an exogenous factor or disruptive event (Krueger 2009; Yessoufou et al. 2018) that has an impact on triggering social entrepreneurial intention, what actually seems to matter most is the support provided by the program staff. It does so by enabling two key processes to occur. On the one hand, it helps to break down the cognitive schemata that are ingrained in a 'poverty mindset'. These cognitive schemata are linked to lower levels of self-confidence and perceived self-efficacy, which in turn dampen 
goal-directed behavior (Haushofer and Fehr 2014), such as social enterprise creation. On the other hand, the support also plays an enabling role as it enhances personal desirability that beneficiaries hold about social entrepreneurship in terms of their social ascension beliefs or what Krueger et al. (2000) called "personal impacts of outcomes". This personal desirability is also intertwined with their resilience and willingness to escape poverty. To these individual variables, we can add collective factors mediated by the community goals of bayanihan and walang iwanan. This also overlaps with Krueger's (2009) notion of perceived social norms and the importance of what significant others think as a precursor of perceived desirability as the common objective that holds the program community together is the eradication of poverty.

Second, while Krueger et al. (2000) state that personal and situational variables typically have an indirect influence as antecedents of entrepreneurial intention, our study shows that in our sample, the desire to escape poverty (personal variable) and social support by the NGO (situational variable) are key factors in developing the social entrepreneurial intention at the BoP. As such, they may have a more important role to play than suggested by the literature so far (Krueger et al. 2000), especially for entrepreneurship in the context of extreme poverty. For the beneficiaries in our sample, social entrepreneurial intention depends on and is created through their NGO support. This seems to confirm Mair and Noboa's (2006) assertion of the importance of the social network as an antecedent to perceived feasibility of a social entrepreneurial project. It is also in line with Yessoufou et al.'s (2018) proposition on the importance of social networks in converting opportunity into action.

Third, our study highlights the importance of building self-confidence among youths at the base of the pyramid as an important step in developing perceived self-efficacy. This is in line with Bandura's (1997) distinction between self-confidence as a common cognitive mechanism for mediating people's motivation, thought patterns, emotional reactions, and behavior; and self-efficacy, which is concerned with the judgments of what an individual can accomplish with a certain set of skills. Brockner (1979) showed that individuals with low self-beliefs typically have an elevated concern about their anxieties and inadequacies that detracts from task performance. Brown (1993) argued that specific beliefs about one's competencies-in other words, perceived self-efficacy-are consequences of self-confidence. Hence, we postulate self-confidence as a critical step is developing the perceived selfefficacy of the youths at the base of the pyramid.

Fourth, BoP youths are strongly motivated by social ascension beliefs in terms in which social enterprises are seen as vehicles through which they may escape poverty. This finding seems to be in line with Yessoufou et al.'s (2018) finding that motivations of selffulfillment, income generation, and wealth creation strengthen the relationship between opportunity development and challenging situations. Our findings, however, do extend their insights, in that beneficiaries are not only concerned about their own emancipation out of poverty but also about ending poverty for the family and community. While from a social entrepreneurial perspective this might not be so surprising as serving the greater good may be imbedded in the raison d'etre of social enterprises, our findings are, to the best of our knowledge, the first to highlight this with regard to social entrepreneurship at the BoP.

Finally, we enrich the model of social entrepreneurial intention by pinpointing the role of social support in developing self-confidence and perceived self-efficacy and adding the role of social ascension beliefs in the context of youths at BoP. So, we extend the model of Hockerts (2017) by prioritizing self-confidence before self-efficacy and confirming the main role of social support.

\subsection{Limitations}

This study has a number of limitations resulting from the choices made in setting up and executing the research. Holstein and Gubrium (2011) argue that the interview situation shapes the form and content of what is being said. Two concerns emerge from this: the asymmetrical relationships between interviewer and interviewee as well as the 
authenticity of participants' accounts. There is also the risk of sample bias. Although we did not identify any factors suggesting systematic biases, respondents who agreed to participate in our study may have different experiences or viewpoints from those who chose not to. Furthermore, the sample is drawn from a specific setting. This research context cautions for generalizations beyond the current sample frame, i.e., people living in poverty in developing countries. Further research in other contexts, experimental or survey-based, might shed further light on our key findings. Indeed, while the choice of our research design (qualitative exploratory inquiry) was motivated by the nature of the research question, we encourage further scholarly work to adopt methodological approaches and sampling methods that allow the validation of our empirical findings.

\section{Conclusions}

In this study, we investigated the emergence of social entrepreneurial intention among youths at the BoP. While the beneficiaries participating in our study had no prior intention of creating their own social enterprise before joining the NGO-run entrepreneurship program, our findings highlight the role of different self-related beliefs (i.e., self-confidence, perceived self-efficacy, and social ascension beliefs) as important drivers in understanding the emergence of social entrepreneurial intention of youths at the base of the pyramid. At a practical level, our study highlights the importance of cognitive social support and suggests that in addition to a focus on the development of entrepreneurship specific knowledge, support mechanisms should also focus on the development of different self-related beliefs to enable the emergence of social entrepreneurial intention at the base of the pyramid.

Our findings highlight a number of implications for research and practice. By combining insights from 'general' entrepreneurial intentions models, social entrepreneurial models, and BoP perspectives, we contribute to furthering our understanding of the emergence of social entrepreneurial intentions amongst disadvantaged populations. Our findings shed a new light on understanding the social entrepreneurial intention among these groups. The most important implication of our findings is the importance of different self-related beliefs in understanding the emergence of social entrepreneurial intentions amongst disadvantaged groups. We argue that it may be important to take self-related beliefs more explicitly into consideration when investigating the levels of social entrepreneurial intention amongst disadvantaged communities. Furthermore, as the literature on the psychology of poverty suggests a link between poverty and reduced levels of self-related beliefs (Haushofer 2013), we encourage future scholarly work to investigate the mechanism about how selfconfidence, and other potential self-related beliefs, contribute to the emergence of social entrepreneurial intention among disadvantaged populations.

With regard to the literature on social entrepreneurial intention, our findings suggest that in addition to self-confidence, social ascension beliefs are an important driver of social entrepreneurial intentions that have thus far not received sufficient attention. Our findings contribute to furthering 'general' entrepreneurial intention models by highlighting collective desirability (eradicating community poverty) in addition to personal desirability as antecedents of perceived desirability. In light of increasing societal attention being dedicated to issues of sustainability (Sachs 2015), this aspect of collective desirability might emerge as an increasingly important driver of social entrepreneurial intentions. Furthermore, our findings suggest that personal and situational variables might be more important than suggested in contemporary models of entrepreneurial intentions (Krueger 2009). Developing the social entrepreneurial intention among the poor, we argue, is different from developing such intentions among non-poor individuals in developed and developing countries.

Author Contributions: Conceptualization, F.C., Y.B., E.T.T.; methodology, F.C., Y.B., E.T.T.; formal analysis, F.C., Y.B.; investigation, F.C., Y.B.; writing-original draft preparation, F.C., Y.B., E.T.T.; writing-review and editing, F.C., Y.B., E.T.T.; visualization, Y.B., E.T.T. All authors have read and agreed to the published version of the manuscript. 
Funding: This research received no external funding.

Informed Consent Statement: Informed consent was obtained from all subjects involved in the study.

Data Availability Statement: The data are not publicly available due to privacy reasons of the respondents.

Conflicts of Interest: The authors declare no conflict of interest.

\section{References}

Acheampong, George, and Mark Esposito. 2014. The Nature of Entrepreneurship in Bottom of the Pyramid Markets. International Journal of Entrepreneurship and Small Business 21: 437-56. [CrossRef]

Agarwal, Nivedita, Ronika Chakrabarti, Alexander Brem, and Nancy Bocken. 2018. Market Driving at Bottom of the Pyramid (BoP): An Analysis of Social Enterprises from the Healthcare Sector. Journal of Business Research 86: 234-44. [CrossRef]

Ajzen, Icek. 1991. The Theory of Planned Behavior. Organizational Behavior and Human Decision Processes, Theories of Cognitive Self-Regulation 50: 179-211. [CrossRef]

Bacq, Sophie, and Elisa Alt. 2018. Feeling Capable and Valued: A Prosocial Perspective on the Link between Empathy and Social Entrepreneurial Intentions. Journal of Business Venturing 33: 333-50. [CrossRef]

Bandura, Albert. 1997. Self-Efficacy: The Exercise of Control. New York: W.H. Freeman and Company.

Bandura, Albert. 2000. Exercise of Human Agency through Collective Efficacy. Current Directions in Psychological Science 9: 75-78. [CrossRef]

Brockner, Joel. 1979. The Effects of Self-Esteem, Success-Failure, and Self-Consciousness on Task Performance. Journal of Personality and Social Psychology 37: 1732-41. [CrossRef]

Brown, Jonathon D. 1993. Self-Esteem and Self-Evaluation: Feeling Is Believing. In Psychological Perspectives on the Self: Volume 4: The Self in Social Perspective. Edited by Jerry Suls. New York: Psychology Press, vol. 4, pp. 27-58.

Bullough, Amanda, Maija Renko, and Tamara Myatt. 2014. Danger Zone Entrepreneurs: The Importance of Resilience and Self-Efficacy for Entrepreneurial Intentions. Entrepreneurship Theory and Practice 38: 473-99. [CrossRef]

Cañeque, Fernando Casado, and Stuart L. Hart, eds. 2017. Base of the Pyramid 3.0: Sustainable Development through Innovation and Entrepreneurship. Abingdon: Routledge.

Carr, Stuart C. 2013. Anti-Poverty Psychology. New York: Springer.

Carr, Stuart C., and Tod S. Sloan, eds. 2003. Poverty and Psychology: From Global Perspective to Local Practice. New York: Springer Science \& Business Media.

Chatterjee, Susmita, Sangita Dutta Gupta, and Parijat Upadhyay. 2018. Empowering Women and Stimulating Development at Bottom of Pyramid through Micro-Entrepreneurship. Management Decision 56: 160-74. [CrossRef]

Claeyé, Frederik, Michael Brookes, and Sandra Ramos. 2020. Social Entrepreneurship as a Vehicle for Inclusive Development. In Business and Development Studies: Issues and Perspectives. Edited by Peter Lund-Thomsen, Michael Wendelboe Hansen and Adam Lindgreen. Routledge Studies in Innovation, Organization and Technology. Abingdon: Routledge, pp. 424-47.

Corley, Kevin G., and Dennis A. Gioia. 2004. Identity Ambiguity and Change in the Wake of a Corporate Spin-Off. Administrative Science Quarterly 49: 173-208. [CrossRef]

Das, Kabita, Rajiba Lochan Behera, and Biswaranjan Paital. 2022. Socio-Economic Impact of COVID-19. In COVID-19 in the Environment. Edited by Deepak Rawtani, Chaudhery Mustansar Hussain and Nitasha Khatri. Amsterdam: Elsevier, pp. 153-90. [CrossRef]

Davidsson, Per, and Benson Honig. 2003. The Role of Social and Human Capital among Nascent Entrepreneurs. Journal of Business Venturing 18: 301-31. [CrossRef]

De Beule, Filip, Martin Klein, and Ernst Verwaal. 2020. Institutional Quality and Inclusive Strategies at the Base of the Pyramid. Journal of World Business 55: 101066. [CrossRef]

Dees, J. Gregory. 1998. Enterprising Nonprofits. Harvard Business Review 76: 54-67. [CrossRef] [PubMed]

Dembek, Krzysztof, Nagaraj Sivasubramaniam, and Danielle A. Chmielewski. 2020. A Systematic Review of the Bottom/Base of the Pyramid Literature: Cumulative Evidence and Future Directions. Journal of Business Ethics 165: 365-82. [CrossRef]

Dolhey, Shivam. 2019. A Bibliometric Analysis of Research on Entrepreneurial Intentions from 2000 to 2018. Journal of Research in Marketing and Entrepreneurship 21: 180-99. [CrossRef]

Donaldson, Colin. 2019. Intentions Resurrected: A Systematic Review of Entrepreneurial Intention Research from 2014 to 2018 and Future Research Agenda. International Entrepreneurship and Management Journal 15: 953-75. [CrossRef]

Donaldson, Colin, Francisco Liñán, and Joaquin Alegre. 2021. Entrepreneurial Intentions: Moving the Field Forwards. The Journal of Entrepreneurship 30: 30-55. [CrossRef]

Dye, Bruce, and Kelly Dye. 2018. Surfacing the Voices of the Other: Female Entrepreneurs in Manila. Journal of Small Business E Entrepreneurship 30: 157-73. [CrossRef]

Francis, Jill J., Marie Johnston, Clare Robertson, Liz Glidewell, Vikki Entwistle, Martin P. Eccles, and Jeremy M. Grimshaw. 2010. What Is an Adequate Sample Size? Operationalising Data Saturation for Theory-Based Interview Studies. Psychology E Health 25: 1229-45. [CrossRef] 
Gaglio, Connie Marie, and Susan Winter. 2009. Entrepreneurial Alertness and Opportunity Identification: Where Are We Now? In Understanding the Entrepreneurial Mind: Opening the Black Box. Edited by Alan L. Carsrud and Malin Brännback. International Studies in Entrepreneurship. New York: Springer, pp. 305-25. [CrossRef]

George, Gerard, Reddi Kotha, Priti Parikh, Tufool Alnuaimi, and Abubakr Bahaj. 2013. Wealth Shocks and Entrepreneurial Intentions: Entrepreneurship in Rural Africa. Academy of Management Proceedings 2013: 12129. [CrossRef]

Gioia, Dennis A., Kevin G. Corley, and Aimee L. Hamilton. 2013. Seeking Qualitative Rigor in Inductive Research: Notes on the Gioia Methodology. Organizational Research Methods 16: 15-31. [CrossRef]

Goyal, Sandeep, Bruno S. Sergi, and Amit Kapoor. 2017. Emerging Role of For-Profit Social Enterprises at the Base of the Pyramid: The Case of Selco. Journal of Management Development 36: 97-108. [CrossRef]

Haushofer, Johannes. 2013. The Psychology of Poverty: Evidence from 43 Countries. Working Paper. Princeton: Abdul Latif Jameel Poverty Action Lab, Massachusetts Institute of Technology, Available online: http:/ / www.princeton.edu/haushofer/publications/ Haushofer_2013.pdf (accessed on 14 February 2018).

Haushofer, Johannes, and Ernst Fehr. 2014. On the Psychology of Poverty. Science 344: 862-67. [CrossRef] [PubMed]

Henning, Sanchen, and Kabira Akoob. 2017. Motivational Factors Affecting Informal Women Entrepreneurs in North-West Province. The Southern African Journal of Entrepreneurship and Small Business Management 9: 1-10. [CrossRef]

Hockerts, Kai. 2017. Determinants of Social Entrepreneurial Intentions. Entrepreneurship Theory and Practice 41: 105-30. [CrossRef]

Holstein, James A., and Jaber F. Gubrium. 2011. Animating Interview Narratives. In Qualitative Research: Issues of Theory, Method and Practice, 3rd ed. Edited by David Silverman. Los Angeles: Sage, pp. 149-67.

Ip, Ching Yin, Chaoyun Liang, Hsiang Ju Lai, and Yuan Jhen Chang. 2021. Determinants of Social Entrepreneurial Intention: An Alternative Model Based on Social Cognitive Career Theory. Nonprofit Management and Leadership 31: 737-60. [CrossRef]

Krueger, Norris F. 1993. The Impact of Prior Entrepreneurial Exposure on Perceptions of New Venture Feasibility and Desirability. Entrepreneurship Theory and Practice 18: 5-21. [CrossRef]

Krueger, Norris F. 2009. Entrepreneurial Intentions Are Dead: Long Live Entrepreneurial Intentions. In Understanding the Entrepreneurial Mind: Opening the Black Box. Edited by Alan L. Carsrud and Malin Brännback. International Studies in Entrepreneurship. New York: Springer, pp. 51-72. [CrossRef]

Krueger, Norris F., and Deborah V. Brazeal. 1994. Entrepreneurial Potential and Potential Entrepreneurs. Entrepreneurship Theory and Practice 18: 91-104. [CrossRef]

Krueger, Norris F., Michael D. Reilly, and Alan L. Carsrud. 2000. Competing Models of Entrepreneurial Intentions. Journal of Business Venturing 15: 411-32. [CrossRef]

Kushnirovich, Nonna, Sibylle Heilbrunn, and Liema Davidovich. 2018. Diversity of Entrepreneurial Perceptions: Immigrants vs. Native Population. European Management Review 15: 341-55. [CrossRef]

Laborde, David, Will Martin, and Rob Vos. 2021. Impacts of COVID-19 on Global Poverty, Food Security, and Diets: Insights from Global Model Scenario Analysis. Agricultural Economics 52: 375-90. [CrossRef] [PubMed]

Liñán, Francisco, and Alain Fayolle. 2015. A Systematic Literature Review on Entrepreneurial Intentions: Citation, Thematic Analyses, and Research Agenda. International Entrepreneurship and Management Journal 11: 907-33. [CrossRef]

Mair, Johanna, and Ignasi Martí. 2006. Social Entrepreneurship Research: A Source of Explanation, Prediction, and Delight. Journal of World Business 41: 36-44. [CrossRef]

Mair, Johanna, and Ernesto Noboa. 2006. Social Entrepreneurship: How Intentions to Create a Social Venture Are Formed. In Social Entrepreneurship. Edited by Johanna Mair, Jeffrey Robinson and Kai Hockerts. Basingstoke: Palgrave Macmillan, pp. 121-35. [CrossRef]

Manzoor, Faiza, Longbao Wei, Mohammad Nurunnabi, and Qazi Abdul Subhan. 2019. Role of SME in Poverty Alleviation in SAARC Region via Panel Data Analysis. Sustainability 11: 6480. [CrossRef]

Miles, Matthew B., A. Michael Huberman, and Johnny Saldaña. 2014. Qualitative Data Analysis: A Methods Sourcebook, 3rd ed. Thousand Oaks: SAGE.

Miller, Danny, and Isabelle Le Breton-Miller. 2017. Underdog Entrepreneurs: A Model of Challenge-Based Entrepreneurship. Entrepreneurship Theory and Practice 41: 7-17. [CrossRef]

Morris, Michael H., Susana C. Santos, and Xaver Neumeyer. 2020. Entrepreneurship as a Solution to Poverty in Developed Economies. Business Horizons 63: 377-90. [CrossRef]

Murphy, Patrick J., and Susan M. Coombes. 2009. A Model of Social Entrepreneurial Discovery. Journal of Business Ethics 87: 325-36. [CrossRef]

Murphy, Patrick J., Artem Kornetskyy, and Joseph T. Nixon. forthcoming. Delineating Novel Aspects of Social Enterprise Theory. Social Enterprise Journal. [CrossRef]

Musona, Jackson, Kaisu Puumalainen, Helena Sjögrén, and Anna Vuorio. 2021. Sustainable Entrepreneurship at the Bottom of the Pyramid: An Identity-Based Perspective. Sustainability 13: 812. [CrossRef]

Naudé, Wim. 2014. Entrepreneurship and Economic Development. In International Development. Ideas, Experiences and Prospects. Edited by Bruce Currie-Alder, Ravi Kanbur, David M. Malone and Rohinton Medhora. Oxford: Oxford University Press, pp. 311-22.

Newey, Lance R. 2018. "Changing the System": Compensatory versus Transformative Social Entrepreneurship. Journal of Social Entrepreneurship 9: 13-30. [CrossRef] 
Pedrozo, Eugenio. 2015. Proposition of BoP 3.0 as an Alternative Model of Business for BoP (Base of Pyramid) Producers: Case Study in Amazonia. In The Challenges of Management in Turbulent Times: Global Issues from Local Perspective. Edited by Marcela Rebeca Contreras Loera and Andrzej Marjański. Mexico City: Universid de Occidente, vol. 189, pp. 189-203.

Périac, Fabrice, Albert David, and Quinetta Roberson. 2018. Clarifying the Interplay between Social Innovation and Sustainable Development: A Conceptual Framework Rooted in Paradox Management. European Management Review 15: 19-35. [CrossRef]

Prahalad, C. K., and Stuart L. Hart. 1999. Strategies for the Bottom of the Pyramid: Creating Sustainable Development. Working Paper. Available online: http:/ / pdf.wri.org/2001summit_hartarticle.pdf (accessed on 21 February 2018).

Raposo, Mário, and Arminda do Paço. 2011. Special Issue: Entrepreneurship and Education-Links between Education and Entrepreneurial Activity. International Entrepreneurship and Management Journal 7: 143-44. [CrossRef]

Rindova, Violina, Daved Barry, and David J. Ketchen Jr. 2009. Entrepreneuring as Emancipation. Academy of Management Review 34: 477-91. [CrossRef]

Sachs, Jeffrey D. 2015. The Age of Sustainable Development. New York: Columbia University Press.

Saebi, Tina, Nicolai J. Foss, and Stefan Linder. 2019. Social Entrepreneurship Research: Past Achievements and Future Promises. Journal of Management 45: 70-95. [CrossRef]

Saldaña, Johnny, and Matt Omasta. 2018. Qualitative Research: Analyzing Life. Thousand Oaks, CA: SAGE Publications.

Santos, Susana C., and Xaver Neumeyer. 2021. Gender, Poverty and Entrepreneurship: A Systematic Literature Review and Future Research Agenda. Journal of Developmental Entrepreneurship 26: 2150018. [CrossRef]

Santos, Susana C., Xaver Neumeyer, and Michael H. Morris. 2019. Entrepreneurship Education in a Poverty Context: An Empowerment Oerspective. Journal of Small Business Management 57: 6-32. [CrossRef]

Schreier, Margrit. 2018. Sampling and Generalization. In The SAGE Handbook of Qualitative Data Collection. Edited by Uwe Flick. London: SAGE, pp. 84-97.

Shapero, Albert. 1984. The Entrepreneurial Event. In The Environment for Entrepreneurship. Edited by C. Kent. Lexington: Lexington Books, pp. 21-40.

Shapero, Albert, and Lisa Sokol. 1982. The Social Dimensions of Entrepreneurship. In The Encyclopedia of Entrepreneurship. Edited by C. Kent, D. Sexton and K. Vesper. Englewood Cliffs: Prentice-Hall, pp. 72-90. Available online: https://papers.ssrn.com/ abstract=1497759 (accessed on 25 May 2018).

Shepherd, Dean A., and Norris F. Krueger. 2002. An Intentions-Based Model of Entrepreneurial Teams' Social Cognition*. Entrepreneurship Theory and Practice 27: 167-85. [CrossRef]

Simanis, Erik, and Stuart Hart. 2008. The Base of the Pyramid Protocol: Toward Next Generation BoP Strategy, 2nd ed. Ithaca: Center for Sustainable Global Enterprise, Cornell University, Available online: http:/ / www.stuartlhart.com/sites/stuartlhart.com/files / BoPProtocol2ndEdition2008_0.pdf (accessed on 15 March 2018).

Sottini, Andrea, Giacomo Ciambotti, and David Littlewood. forthcoming. Engaging Symbiotic Ecosystems to Build Community Centred Business Models for the BoP: Evidence from Small Social Enterprises in East Africa. International Small Business Journal. [CrossRef]

Strauss, Anselm L., and Juliet M. Corbin. 1990. Basics of Qualitative Research: Grounded Theory Procedures and Techniques. Newbury Park: Sage.

Sutter, Christopher, Garry D. Bruton, and Juanyi Chen. 2019. Entrepreneurship as a Solution to Extreme Poverty: A Review and Future Research Directions. Journal of Business Venturing 34: 197-214. [CrossRef]

Tan, Luc Phan, Angelina Nhat Hanh Le, and Lan Pham Xuan. 2020. A Systematic Literature Review on Social Entrepreneurial Intention. Journal of Social Entrepreneurship 11: 241-56. [CrossRef]

Tracy, Sarah J. 2020. Qualitative Research Methods: Collecting Evidence, Crafting Analysis, Communicating Impact, 2nd ed. Hoboken: John Wiley \& Sons.

Trivedi, Smita K., and Antoaneta P. Petkova. 2021. Women Entrepreneur Journeys from Poverty to Emancipation. Journal of Management Inquiry. [CrossRef]

Usman, Sumaiya, Fazeelat Masood, Mubashir Ali Khan, and Naveed ur Rehman Khan. 2022. Impact of Empathy, Perceived Social Impact, Social Worth and Social Network on the Social Entrepreneurial Intention in Socio-Economic Projects. Journal of Entrepreneurship in Emerging Economies 14: 65-92. [CrossRef]

Venugopal, Srinivas, Madhubalan Viswanathan, and Kiju Jung. 2015. Consumption Constraints and Entrepreneurial Intentions in Subsistence Marketplaces. Journal of Public Policy \& Marketing 34: 235-51. [CrossRef]

Yamini, Reza, Daria Soloveva, and Xiaobao Peng. forthcoming. What Inspires Social Entrepreneurship? The Role of Prosocial Motivation, Intrinsic Motivation, and Gender in Forming Social Entrepreneurial Intention. Entrepreneurship Research Journal 1. [CrossRef]

Yessoufou, Ahoudou W., Vincent Blok, and S. W. F. Omta. 2018. The Process of Entrepreneurial Action at the Base of the Pyramid in Developing Countries: A Case of Vegetable Farmers in Benin. Entrepreneurship E Regional Development 30: 1-28. [CrossRef]

Zhang, Yang, Juanita Trusty, Tatiana Goroshnikova, Louise Kelly, Kwok K. Kwong, Stephen J.J. McGuire, Juan Perusquia, Veena P. Prabhu, Minghao Shen, and Robert Tang. 2021. Millennial Social Entrepreneurial Intent and Social Entrepreneurial Self-Efficacy: A Comparative Entrepreneurship Study. Social Enterprise Journal 17: 20-43. [CrossRef] 